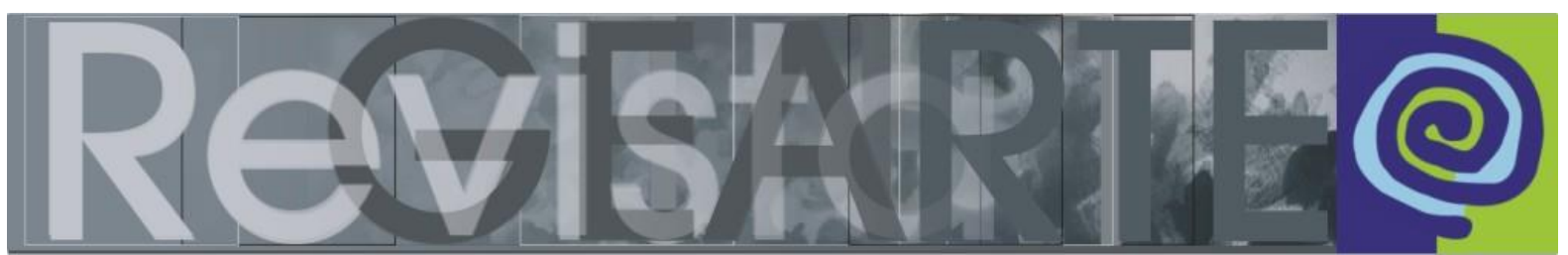

ISSN 2357-9854 | e-ISSN 2596-3198 (online)

\title{
O fazer sensível de Nelma Pezzin: artista e professora
}

\author{
Moema Martins Rebouças \\ (Universidade Federal do Espírito Santo — UFES, Vitória/ES, Brasil)
}

\begin{abstract}
RESUMO - 0 fazer sensível de Nelma Pezzin: artista e professora - Este texto tem como objetivo principal recuperar práticas artísticas e docentes para interrogar como a poeticidade de um fazer sensível atua e faz sentido. Tem como hipótese que a Arte e os processos artísticos nutrem a docência e instituem metodologias e práticas educativas em contextos de ensino. Elege como corpus uma das 10 artistas integrantes da pesquisa "O lugar do discurso na Arte e na Docência: entrelaçamentos e articulações tecidas em contextos educativos", que foram professoras no Centro de Artes da Universidade Federal do Espírito Santo (UFES), desde o ano de 1976. Utiliza Duve como referencial para o ensino superior e Fiorin, Landowski, Oliveira para as análises na abordagem semiótica. Conclui que as relações entre a Arte e o ensino são de trocas e a educação é partilha. A "forma de vida" da professora artista, ou o que a faz-ser tem na articulação das práticas artísticas e docentes a sua própria constituição como sujeito.
\end{abstract}

PALAVRAS-CHAVE

Artista e professora. Narrativas. Ensino de Artes Visuais.

RESUMEN - El trabajo sensible de Nelma Pezzin: artista y profesora - En este texto, el objetivo principal es recuperar las prácticas artísticas y de enseñanza para interrogar cómo la poética de un trabajo sensible actúa y tiene sentido. Se presume que el Arte y los procesos artísticos nutren la enseñanza e instituyen metodologías y prácticas educativas en contextos de enseñanza. Elige cómo corpus a una de las 10 artistas que participan en la investigación "El lugar del discurso en el Arte y la enseñanza: entrelazados y articulaciones tejidas en contextos educativos", que eran docentes en el Centro de Artes da Universidade Federal do Espírito Santo (UFES), desde 1976. Se utiliza Duve como referencia para la educación superior y Fiorin, Landowski, Oliveira para el análisis del enfoque semiótico. Concluye que las relaciones entre el Arte y la enseñanza son de intercambio y la educación es compartir. La "forma de vida" de la artista profesora, o lo que la hace-ser tiene en la articulación de las prácticas artísticas y docentes su propia constitución como sujeto.

PALABRAS CLAVE

Artista y profesora. Narrativas. Educación Artística.

ABSTRACT - Nelma Pezzin's sensitive doing: artist and teacher - The aim in this text is to recover artistic and teaching practices to question how the poeticity of a sensitive doing acts and makes sense. It is hypothesized that Art and artistic processes nurture teaching, and institute methodologies and educational practices in teaching contexts. Its corpus is one of the 10 artists from the research "The place of discourse in Art and Teaching: intertwining and articulations woven in educational contexts", who have been professors at the Arts Center of the Federal University of Espírito Santo (UFES), since 1976. It uses Duve as reference for graduate education and Fiorin, Landowski, Oliveira for the semiotic approach analysis. It concludes that the relations between Art and teaching are considered interrelations and education is sharing. The "life form" of the artist teacher, or what she does, has in her articulation of artistic practices and teachers her own constitution as a subject.

\section{KEYWORDS}

Artist and professor. Narratives Visual Arts Teaching. 


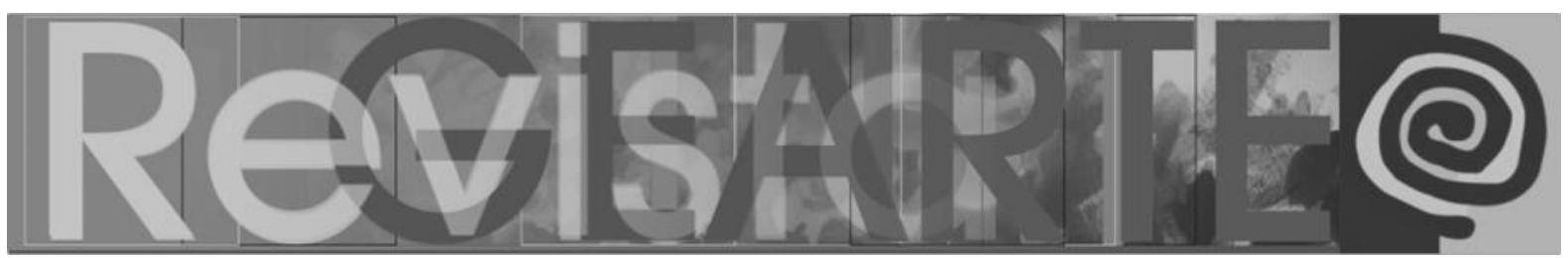

Como parte da pesquisa "O lugar do discurso na Arte e na Docência: entrelaçamentos e articulações tecidas em contextos educativos" ${ }^{1}$, que tem como corpus dez artistas que ingressaram como professores no Centro de Artes da Universidade Federal do Espírito Santo (CAR/UFES) a partir de 1976, este artigo elege para reflexão e análise, a artista e professora Nelma Pezzin. O objetivo do artigo é o de compreender como as práticas artísticas e docentes articulam-se e, desse modo, interrogar como a poeticidade de um fazer sensível atua e faz sentido. A hipótese é a de que a Arte e a produção artística nutrem a docência e instituem metodologias e práticas educativas em contextos de ensino.

\section{Como dados empíricos² utilizaremos:}

1- Documentos primários de docência, tais como programas e planos de ensino, memorial descritivo docente e, no segundo grupo, documentos da produção artística, como catálogos de exposição, imagens de obras tais como de desenho, pintura e gravuras realizadas pela artista;

2- Transcrição da entrevista/conversa (filmada para compor documentário sobre a artista).

Como referencial sobre o ensino da arte em instituições de formação superior recorremos a Duve (2012). Para reflexão e análise elegemos a sociossemiótica proposta por Eric Landowski (1992, 2001, 2014, 2016). Essa abordagem possibilitará a análise das manifestações significantes inscritas nesses documentos, para delas apreender os modos de constituição do fazer sensível da artista e professora Nelma Pezzin. Conforme sugestão de Landowski (2001, p. 23), para que possamos captar os sentidos construídos e articulados nessas práticas

1 Pesquisa realizada pelo GEPEL (Grupo de Pesquisa de Processos Educativos em Arte), financiada pelo Conselho Nacional de Desenvolvimento Científico e Tecnológico-Cnpq e pela FAPES (Fundo de Amparo a Pesquisa do Espírito Santo.

2 Os dados produzidos pela pesquisa somam, até o momento, 502 documentos digitalizados e as 10 entrevistas em audiovisual dos artistas e professores. Entre este material constam os que serão utilizados neste artigo. 


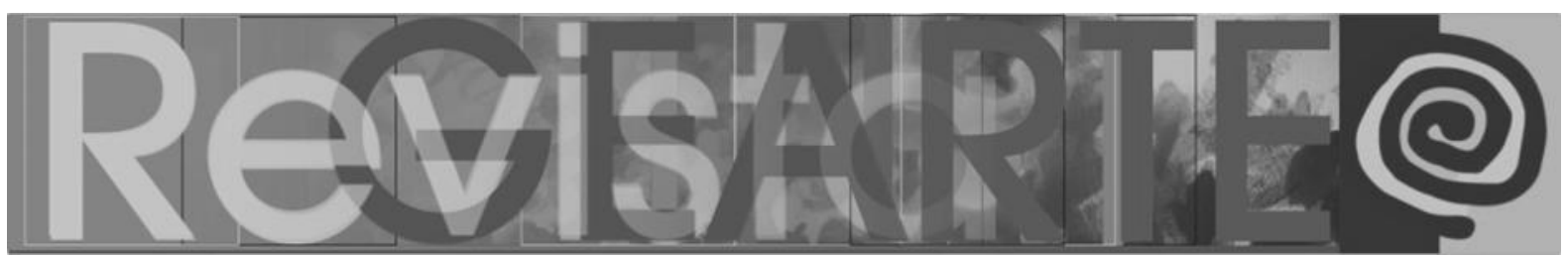

artísticas e docentes é preciso descrevê-las e analisar o material que temos, com o intuito de resgatar a sua singularidade e especificidade.

Consideramos o conceito de práxis enunciativa para explicar a copresença de elementos de diferentes estatutos, em que a enunciação individual está em relação às enunciações coletivas que a antecederam e a tornam possível. Portanto, os usos e as práticas sedimentadas pela história determinam os atos de linguagem:

\begin{abstract}
O enunciador, no momento da enunciação, convoca, atualiza, repete, reitera um "já dado" (gêneros, modos de dizer etc.), mas também o revoga, recusa-o, renova-o e transforma-o. Há um domínio do impessoal que rege a enunciação individual. É preciso ficar claro, no entanto, que, muitas vezes, a enunciação individual insurge-se contra esses modos de dizer sedimentados, dando lugar a práticas inovadoras, que criam significações inéditas. (FIORIN, 2010, p. 62).
\end{abstract}

As práticas resultantes desses atos, materializadas em documentos, são produtos de uma dada época, e a recuperação dessa história produtiva realizada e compartilhada pelo próprio sujeito da enunciação a transforma em um acontecimento discursivo.

Outra noção a ser considerada neste estudo é a que interroga os regimes de sentido e as formas de educação, para que possamos refletir sobre "o sentido de nossas escolhas de sociedade e, mais amplamente, de nossas formas de vida" (LANDOWSKI, 2016, p. 8).

\title{
Primeira ruptura com o dever: modalizada pelo querer
}

[...]...eu desenho desde que eu era pequena, sempre gostei de desenhar. $\mathrm{Na}$ escola eu que fazia os trabalhos de desenho para todo mundo. $\mathrm{Na}$ época do vestibular meu pai queria que eu fizesse Economia. Aí fui fazer o cursinho e fiquei até o finalzinho na sala de Economia, que antes era separada [...], junto com Administração, Economia e Engenharia. Só que eu não gostava, estava sendo pressionada. [...] Chegou na última hora, na hora de preencher ... eu falei, não vou fazer... vou fazer Artes. Foi aquela decepção[...] (PEZZIN, 2018). ${ }^{3}$

3 Conversa/entrevista com a artista concedida para o GEPEL e realizada em seu Atelier em 10/05/2018. 


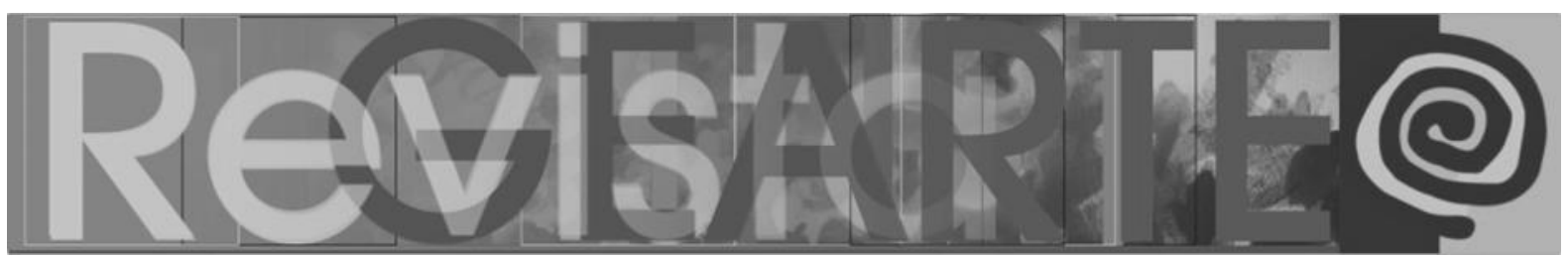

No segundo semestre de 1973 Nelma Pezzin inicia o seu Curso de Bacharelado em Artes Plásticas na UFES e o conclui em 1978. Ao contrariar a família, preocupada com o destino profissional que tal escolha acarretaria, opta por atender aos seus próprios desejos. Não-pode-não-fazer, desse modo, quebra o "dever" imposto pelo pai. Em 1979, um ano após formada, inicia a sua carreira docente na mesma instituição em que se formou. O percurso desses seis anos demonstra como a práxis enunciativa coletiva e social presente no discurso da família sobre a Arte e a profissão de artista foram confrontadas e rompidas por Nelma. Essa ruptura com o discurso social faz com que assuma a posição actancial de sujeito de sua própria enunciação, aquele cujo ato "faz ser o sentido" (LANDOWSKI, 1992, p. 167).

Para a semiótica, a intencionalidade é uma relação orientada e por meio dela o sujeito constrói o mundo como objeto e, ao mesmo tempo, constrói a si mesmo (GREIMAS; COURTÉS, s/d, p. 147). É também Landowski (1997) quem argumenta que "gosto se discute". Ao discutir o gosto, o autor defende ser esse orientado como uma construção edificada na e pela relação entre sujeito e objeto. Do ponto de vista de quem provoca o gosto, defende que esse pode ser classificado como objetal, que é quando o prazer é produzido pelos objetos e de subjetal, quando produzido pelo próprio sujeito por intermédio da relação direta consigo mesmo ou com um outro.

O prazer pelo desenho, resgatado de um passado distante e manifestado na narrativa da Nelma para justificar a sua escolha é tanto objetal como subjetal. Nos comentários de Oliveira (2003, p. 69) está a defesa desse argumento:

[...] apreciar o gosto do gosto do sentido, a um querer cultivá-lo pois a intimidade maior com tal fonte de prazer é uma das condições para sentir o seu gosto com mais intensidade e em toda a sua gama de sutilezas que ensinam, por elas mesmas, a significação de sua matéria significante. Somente o sentir de um gosto ensina as suas variabilidades e a experimentação continuada destas desenvolve estesicamente a sua apreciação. 


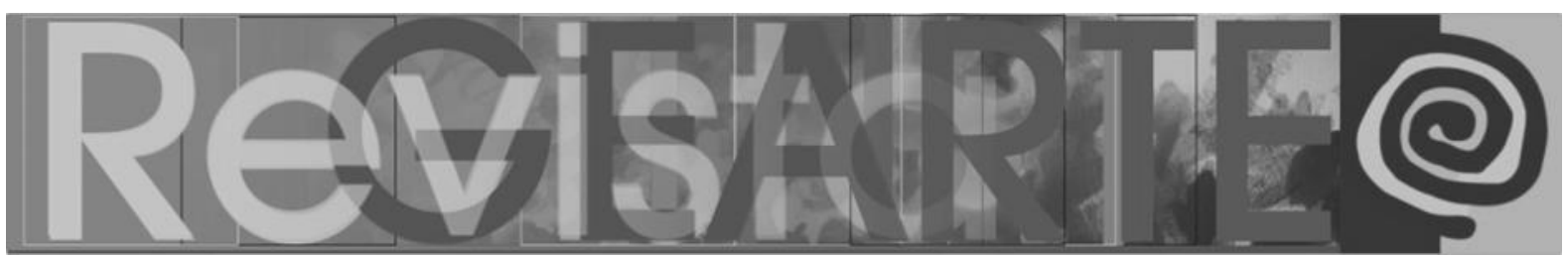

Experimentar o sabor, diversificar os pontos de vista sobre o mesmo objeto e diferenciar as experiências constituem as condições para o apreciador, ele mesmo constituído nessa interação; condições para um artista, ele mesmo um fruidor.

\section{Práticas e modos de "transmissão"}

Será que falamos de modo sensato quando dizemos que a finalidade de uma escola de arte é formar artistas, assim como a finalidade de uma escola de medicina é formar médicos? (DUVE, 2012, p. 240)

O Curso de Bacharelado em Artes Plásticas, em 1973, possuía uma base curricular na qual estava incluída tanto a herança clássica da Escola de Belas Artes como a proposta técnica da Bauhaus. A ênfase nas disciplinas de desenho Desenho Artístico I, II, II; Desenho Anatômico; Desenho de Croquis I, II; Desenho de Modelo Vivo I, II, como preparatórias para as linguagens da Gravura, Pintura e Escultura (essas ofertadas ao fim do curso) - denotam a permanência de um currículo pautado a partir de uma formação mais especializada e técnica. O que se esperava é que o estudante ao final do curso pudesse ser um desenhista, um pintor, um gravador ou um escultor. Ou, ainda, que pudesse dedicar-se a mais de uma dessas linguagens. Mas os cursos de Artes formam ou formavam artistas?

O ensino superior tem como função formar profissionais e/ou pesquisadores. Considerando que ensinar é transmitir ${ }^{4}$ (DUVE, 2012; LANDOWSKI, 2016), essa transmissão pode ocorrer de diferentes modos e aportes. Podemos afirmar que nas artes, diferente do conhecimento científico, que é de caráter geral, o enfoque não está na comunicação atual dos conhecimentos e nem em generalizações (ZAMBONI, 1998). Para Duve, "[...] em arte, o estado atual dos conhecimentos é uma expressão vazia, pois não há saber artístico separável do ato de transmissão pelo qual o ofício é obtido, o gosto se forma, a cultura se propaga (DUVE, 2012, p. 159).

4 Embora a perspectiva da transmissão no ensino esteja mais próxima às pedagogias tradicionais, os autores citados problematizam e extrapolam essa destinação e atribuem sentidos mais complexos ao termo, sem, contudo, abdicar dele. 


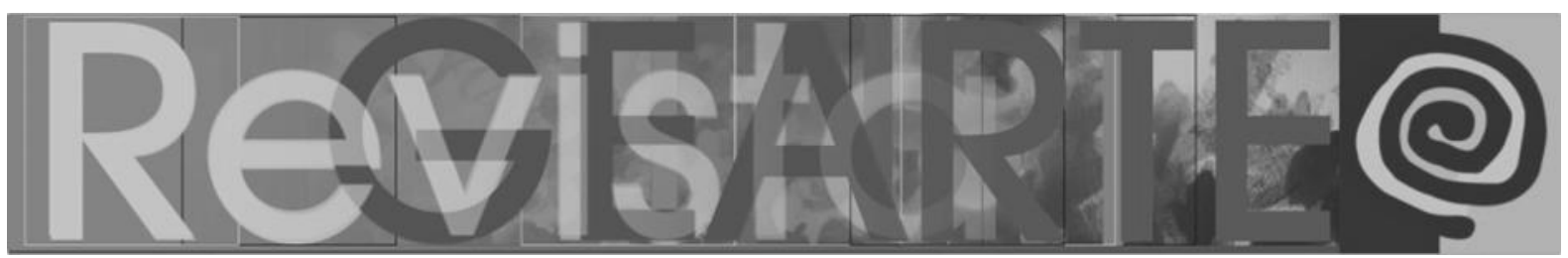

Nessa perspectiva, os artistas no decorrer da história e em diferentes sociedades, com seus diversos e diferentes valores, não pararam de praticar. Duve (2012) denomina de "tradição" essa continuidade de práticas artísticas, mesmo que seus projetos e expressões formais constituam rupturas ao longo desse tempo. A defesa é a de que as rupturas correspondem aos modos da transmissão. Do aprendiz da Idade Média ou do aprendiz das oficinas de Arte em qualquer tempo em que ela ocorria. Quando diretamente do mestre, como nas Academias e Escolas de Belas Artes, alcançavam o prestígio novo e exclusivo do próprio espaço de "poder" e de "saber", sendo ali reconhecidas como tal.

Para Duve (2012) os modos de transmitir ou de comunicar a tradição podem ser divididos em três: o técnico, o teórico e o estético. No primeiro, o aprendizado se realiza quando o aprendiz observa o fazer do professor e o imita ou, ainda, autonomamente faz por si, inova e cria. Ao romper com o programado e inovar, rompe com o destino do corporativismo, prática que regia as guildas da Idade Média. No segundo modo - o teórico - o programa se pauta em um ensino baseado na comunicação de princípios e regras e cabe ao aluno o dever-fazer ou cumprir o programa determinado por uma autoridade superior. A relação, como no primeiro programa, é também verticalizada. Esse segundo modo é o que rege o princípio das Academias do século XVI ao século XVIII. Nesse modo de educar, a crença é que a transmissão se dá quando o mestre fornece aos alunos algo que Ihes permitirá alçar voos, entretanto desde que esses sejam submetidos às provas e avaliações reguladas pelo sistema destinador, ou seja, o da Academia. São, portanto, os mestres que sancionam os alunos.

E, por fim, o terceiro modo, que é a estética, tem como princípio a formação do julgamento e do gosto. Como no segundo, é o professor que elege o que considera exemplar para transmitir aos alunos, utilizando modelos que formam "o gosto", que atendem a determinadas culturas e, no caso das Artes, aos valores que defendem. É o caso da escolha por um aspecto da história da arte que revela o recorte de mundo, igualmente ideologizado que narra (BUORO, 2002). 


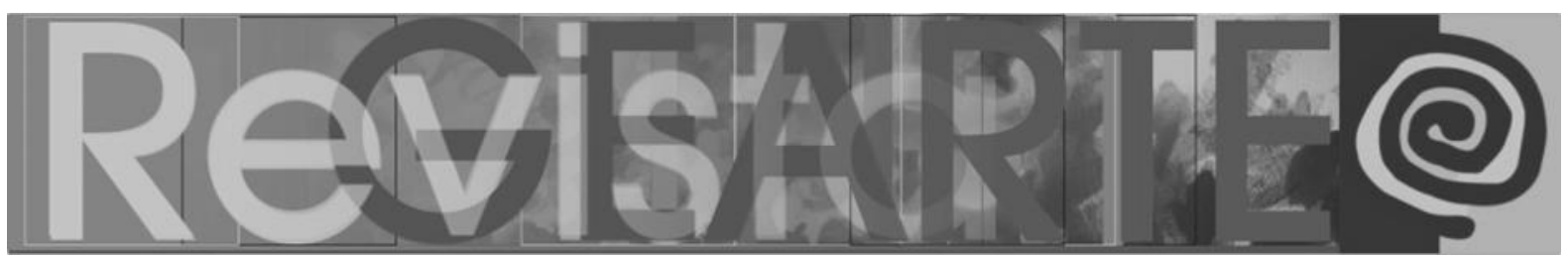

ensino superior de Artes conserva em suas bases esses três modos de transmitir, ora valorizando um, ora outro. A mudança implica a própria proposição da Arte na contemporaneidade e o Curso de Bacharelado de Artes Plásticas na UFES não é uma exceção.

No decorrer dos cursos de Artes, poucos estudantes rompem o que está programado (cumprir o que o professor e a disciplina elegem como princípio de transmissão). Romper, nessa perspectiva, é inovar e assumir um repertório poético próprio, que o designaria como um artista e não unicamente como um estudante seguidor e cumpridor do programa narrativo proposto a ele.

\section{Só se aprende a desenhar desenhando muito: viver o desenho}

[...] Quando comecei a desenhar modelo, foi a coisa mais assim...fiquei louca. [...] Em casa eu desenhava todo mundo. Desenhava meu pai, desenhava minha irmã, desenhava minha mãe. Assim que fui trabalhando o desenho, cada vez mais. A escola foi um diferencial muito grande, eu gostava... era aquilo que eu queria, mas tudo era muito novo. Eram muitas áreas, muitos materiais, mas no decorrer do curso o que eu mais gostava era o desenho mesmo. [...] Participava de exposições, salões, sempre na área de desenho. Na gravura, Samú era o Professor e estimulava muito a experimentar, assim fiz todas as gravuras e no final, a litografia foi a que mais me aproximei por conta do desenho gestual. Como desenho tem mais a ver com o gesto, com a mancha, foi ali que me encontrei. $\mathrm{Na}$ época tinha um programa do MEC chamado Bolsa Pesquisa Arte, e pude me aprofundar, ainda era aluna. (PEZZIN, 2018).

O programa Bolsa Arte foi instituído pelo Ministério de Educação e Cultura - MEC, em finais da década de 1970 e início da de 1980. Destinado aos estudantes de ensino superior das áreas de Artes (Artes Plásticas, Música e Literatura), a adesão ocorria mediante a apresentação de um projeto de pesquisa na área das Artes, submetido pelo graduando interessado em desenvolver um trabalho próprio. Os selecionados recebiam apoio material e orientação individual de um ou dois professores cadastrados no programa e pertencentes à instituição. Entre os estudantes do curso de Artes, do Centro de Artes da UFES, poucos ${ }^{5}$ integraram

5 Em 1980 eram seis estudantes do Programa Bolsa Arte na UFES, conforme catálogo da exposição itinerante. Na entrevista em 1978 Nelma cita o nome de Neusa Mendes, Denise Pimenta e o seu próprio. 


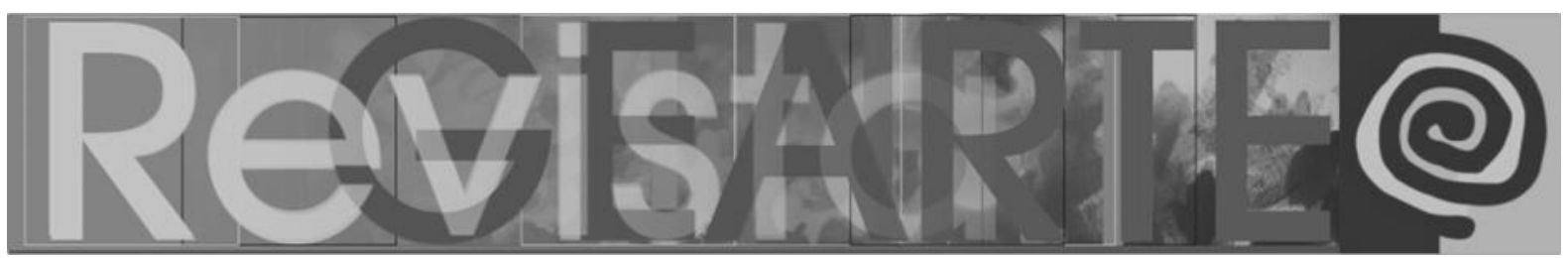

esse projeto, devido a um número específico e reduzido de bolsas e exigência do desenvolvimento do projeto individual a ser realizado no período de até um ano, passível de prorrogação. Os integrantes, além do apoio destacado, participavam de exposições coletivas e itinerantes junto com os demais bolsistas de outras instituições de ensino e de encontros de pesquisa nacionais. Como participante nesse programa, Nelma viveu a pesquisa em Arte desde que ingressou na universidade. O desenhar constante a fez viver o desenho!

A consulta aos programas das disciplinas básicas de Desenho do curso ${ }^{6}$ ofertadas nos primeiros semestres letivos confirma a presença de um ensino pautado em um modo de transmissão técnico. Num recorte em três disciplinas, o Quadro 1 elege os objetivos gerais incluídos nos programas, para que possamos analisar os princípios que regem essas disciplinas ou compreender qual paradigma de desenho constitui a base para a formação do artista. Numa sequência, em que a primeira que consta no quadro é a primeira a ser ofertada, elegemos as disciplinas de Desenho de Croquis, Desenho de Modelo Vivo I e Desenho Anatômico.

Quadro 1 - Disciplinas de Desenho ofertadas para os cursos de Bacharelado e Licenciatura em Artes Visuais pelo Departamento de Formação Artística-Centro de Artes/UFES

\begin{tabular}{|l|l|}
\hline Disciplina & Objetivos gerais \\
\hline D. de Croquis & $\begin{array}{l}\text { a) estimular a percepção visual; } \\
\text { b) desenvolver a sensibilidade artística; } \\
\text { c) perceber o todo e, em particular as formas particulares dos objetos; } \\
\text { d) valorizar a perspectiva de observação; } \\
\text { e) perceber e desenvolver valores reais e particulares da figura humana. }\end{array}$ \\
\hline D. Modelo Vivo I & $\begin{array}{l}\text { a) iniciar no domínio da capacidade de representação gráfica da forma humana; } \\
\text { b) noção de plano, forma e figura humana (aprofunda conhecimentos técnicos } \\
\text { através de usos de matérias oferecendo condições para o maior domínio da } \\
\text { representação da forma humana; pontos de referência e perspectiva-fundo e } \\
\text { figura, espaço negativo; } \\
\text { c) interpretação da figura humana (orienta os alunos no sentido da interpretação } \\
\text { através da análise pessoal da figura humana); } \\
\text { d) propõe grandes composições livres e dá informações técnicas a diferentes } \\
\text { propostas. }\end{array}$ \\
\hline D. Anatômico & $\begin{array}{l}\text { a) conhecer a forma anatômica do modelo; } \\
\text { b) definir o modelado e sua estrutura. }\end{array}$ \\
\hline
\end{tabular}

Fonte: Arquivo do Departamento de Formação Artística-Centro de Artes/UFES.

6 Disciplinas ofertadas pelo Departamento de Formação Artística. Programas de 1976 a 1977. 


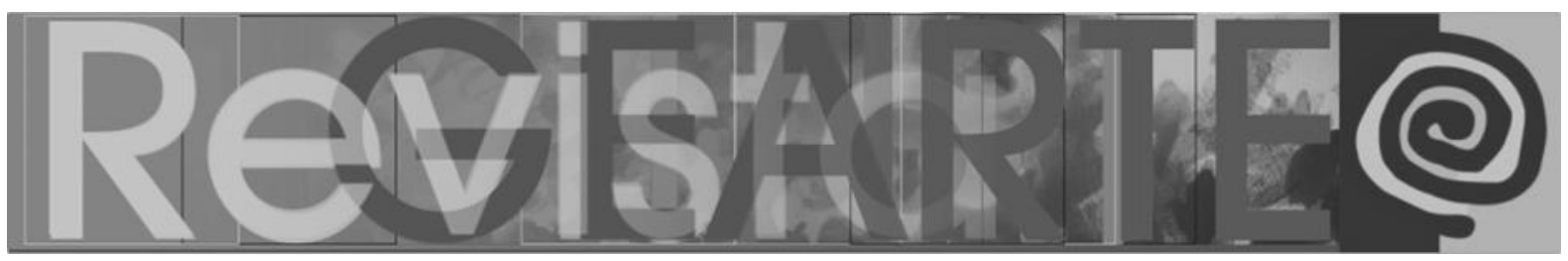

Desde o primeiro semestre letivo, o desenho da figura humana está inserido nas disciplinas ofertadas. Justifica, portanto, a performance da Nelma ao buscar a competência e exercitar o treino do desenho de figura humana, até mesmo com a sua própria família. A repetição da experiência faz com que o sujeito perceba e se aproprie daquela figuração que the é apresentada e que ele tem como dever conforme o que está programado e com o uso de recursos técnicos - reproduzir. Nos programas a ênfase está na apropriação desse referente externo. É a modelo que, ao ocupar o espaço central da sala, que os alunos devem observar, buscar os detalhes, as proporções e dimensões e tal qual numa estética clássica "transferir" essas propriedades observadas para o seu desenho. A ênfase no referente e a verossimilhança é valor. Entretanto, tal como um cubo ou um banco, esse corpo está despossuído, "[...] ao lado de outras figuras, é uma forma comparável a outras formas". (GREIMAS, 1975, p. 53). Bancos, cubos e corpos da modelo estão ali para que o estudante capte a forma, a luz, o volume e num suporte bidimensional, recrie esse "modelo" nos fazendo crer pelo fazer-parecer.

Os manuais e a repetição da experiência possibilitam o aprendizado desse tipo de desenho. Portanto, o estudante de Artes Plásticas poderá ao final do curso atender aos objetivos das disciplinas referentes à utilização das técnicas e dos materiais, entretanto esses fatores auxiliam na apropriação do desenho como base de conhecimento e de comunicação entre a humanidade, mas não formam o artista.

Desenhar a figura humana é assumir a visão clássica de fazer-parecer-real ao que é plasticidade da linguagem expressiva do desenho. É produzir ilusões e reproduzir indefinidamente o ideal pertencente à determinada estética. Dominar a representação inclui esse procedimento num modo de ensino pautado na transmissão que privilegia a técnica. Essa é a práxis enunciativa presente na formação e com ela convive uma outra que atribui ao sujeito, nesse caso o estudante, uma expectativa de, por meio da repetição e apropriação dessas ações programadas e previstas nas disciplinas, poder desenvolver a sensibilidade artística, tal como consta entre os objetivos da Disciplina Desenho de Croquis. 


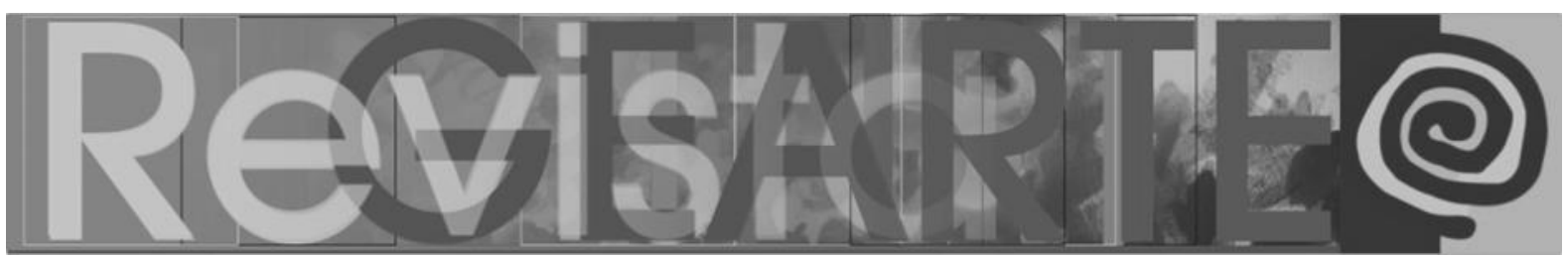

Contudo, a análise dos objetivos do Quadro 1 expõe um modo técnico de "transmitir" a tradição. Para alcançar esse êxito, o de aquisição do desenho, o estudante deverá atender à expectativa do "mestre", reconhecendo essa relação verticalizada e as persuasões de um dever-fazer, de um fazer-fazer e de um nãopoder-não-fazer.

Contudo, para superar a transmissão técnica, o desenho pode assumir um outro papel, tal como define Bismarck (2001, p. 58)

Parece-me então que a primordial função pedagógica do desenho como disciplina curricular será a de fundamentar e desenvolver esse espaço de disponibilidade, de investigação, esse espaço íntimo, reservado, impartilhável que é o desenho como acto, que é o desenhar.

\title{
Trabalho poético e a impermanência: um busca o outro e o outro...
}

\begin{abstract}
Esse espaço que se situa entre a ideia e a sua imagem, esse espaço que trabalha a ideia, que a reconfigura, que coloca em evidência o fazer, que convoca e coloca em confronto o passado e o futuro, o conhecido e o desconhecido, o conhecimento e o reconhecimento, a tradição e o novo, as linguagens gráficas, as suas convenções e as suas limitações, esse é o espaço onde o desenho se faz, esse é o espaço operativo do desenho, é aí que o desenho se resolve. (BISMARCK, 2001, p. 55)
\end{abstract}

Espaço que para existir tem de superar a técnica pela técnica, a disciplina pela criação e transformar o corpo da modelo, que era só forma, em um corpo sentido (LANDOWSKI, 1996). Nesse ato, o desenho assume um outro valor, não mais o de cumprir o programado, mas de romper o previsto e se afirmar como trabalho poético. A interação não é mais entre o "corpo" objeto, mas em sentir o corpo do outro e como o desenho o faz visível. Conforme Bismarck (2001), o desenho, ao assumir essa passagem de ideia, ou de desenho internalizado para desenho externo, ocupa um tempo/espaço de ação e se institui como processo, como ato, e não como resultado. Nessa perspectiva, desenho é ação e é processo, ao incluir a investigação do próprio pensamento antes de se configurar como forma. Como dispensa materiais complexos - basta um lápis e um papel - o desenho possibilita a rapidez e a proximidade entre o fazer e o pensar (BISMARCK, 2001). Contudo, o desenho busca "[...] um outro e um outro", 


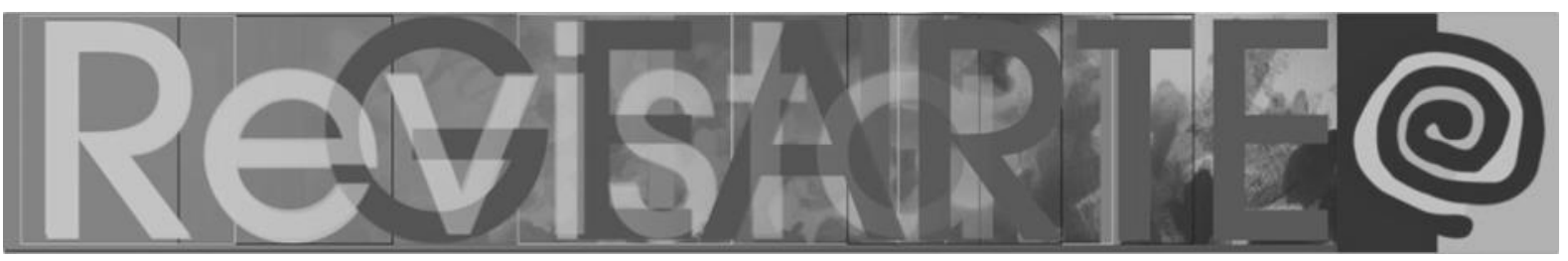

conforme nos relata Nelma (2018), ao relacionar o desenho com a gravura ou um desenho com outro. É efêmero e é contínuo.

Desde estudante, o desenho de Nelma assume posições que transitam entre o exercício em se constituir como processo e gestualidade. O desenho é linguagem expressiva. Em 1978, ainda estudante, recebeu o 1ํPêmio Desenho no III Salão Nacional Universitário de Artes Plásticas. Os salões, atualmente considerados anacrônicos, atuaram desde a década de 70 até os anos iniciais do século XXI como abalizadores das produções de novos artistas. Promovidos por instituições culturais públicas, como os salões universitários, cumpriam a função de avaliar e dar visibilidade a esses artistas. Em 1979, Nelma participa do III Salão Universitário de Artes Plásticas e recebe o 1ํPrêmio de Desenho (PEZZIN, 2008). As Figuras 1, 2 e 3 são desenhos da artista realizados em 1977, 1978 e em 1979.

Figura 1 - 0 paraíso está na sua frente, $1977,63,5$ x 45,5cm

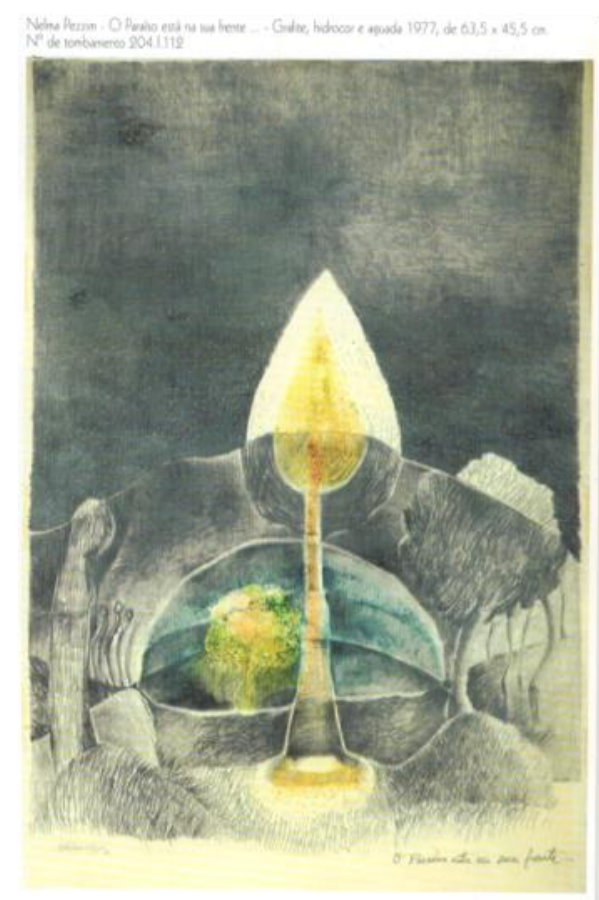

Fonte: Acervo da Coleção de Arte da UFES.
Figura 2 - Gente, 1978, 31 x 22,2 cm

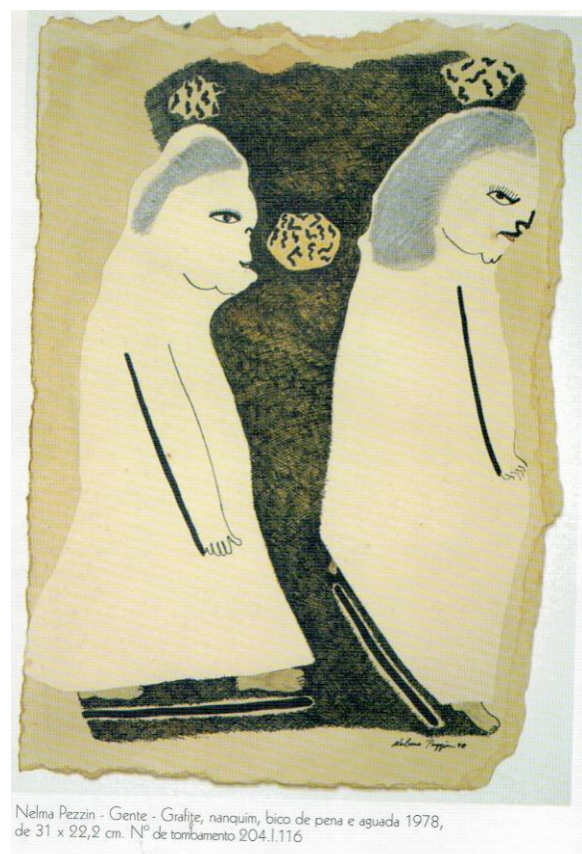

Fonte: Acervo da Coleção de Arte da UFES. 


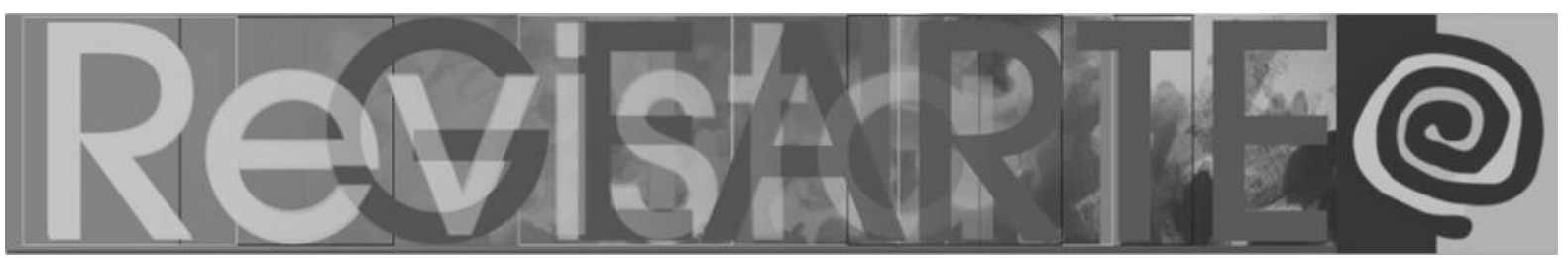

Figura 3 - Imagem número dois, 1979, 40 x 55 cm

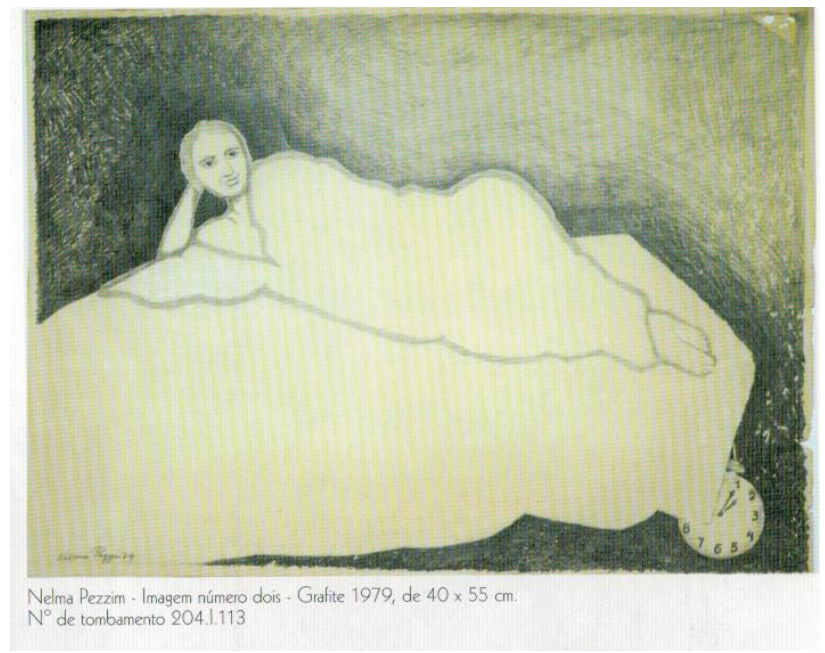

Fonte: Acervo da Coleção de Arte da UFES.

No desenho O paraíso está na sua frente (Figura 1) a artista explora os materiais numa conjunção de técnicas, mas evoca a práxis enunciativa de determinado tempo/espaço da história da arte, numa interdiscursividade em que as influências clássicas organizam a sua paisagem mítica. Para tanto, elege uma espacialidade em que a simetria e a centralização da figura central dominam a cena. Reforça essa dualidade, ao dividir a verticalidade da superfície planar em duas, incluindo na parte de baixo uma figuratividade plena de traços do estilo surrealista. A artista carrega para sua produção plástica o aprendizado obtido com outros artistas da modernidade que o curso Ihe permitiu conhecer e pesquisar.

No desenho Gente (Figura 2) estão duas figuras de perfil marcadas pela quase ausência de traços no interior de suas formas. Aqui toda a superfície da folha recebe as inscrições feitas a bico de pena na parte central e em aguada em todo o entorno para, nesse proceder, deixar surgir os corpos de perfil. $O$ desenho revela a busca por uma solução formal própria da artista. Os exercícios processuais que o geraram adquirem maturidade poética ao constituírem-se como um traço poético próprio e não mais preso a determinado estilo.

No desenho Imagem número dois (Figura 3) Nelma retoma a pesquisa pela história da arte e, somente com grafite, faz surgir um corpo coberto deitado sobre 


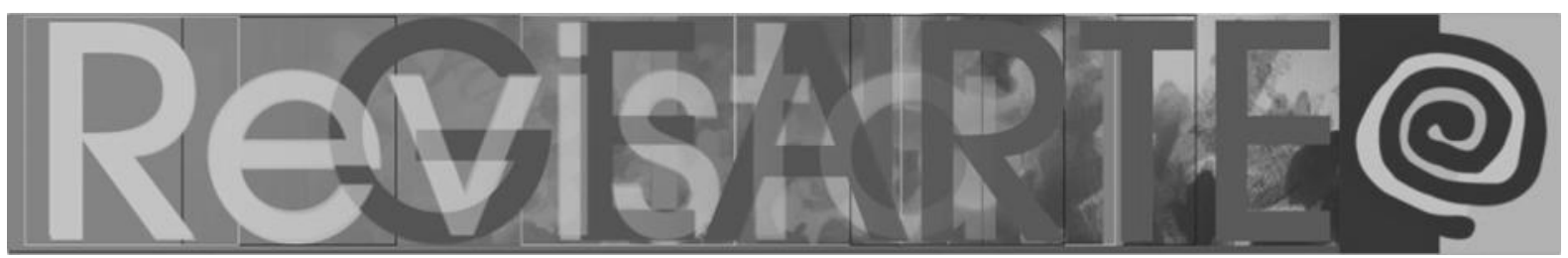

uma superfície construída pela ausência do grafite que, ao mesmo tempo, delimita o corpo. A artista explora as possibilidades da materialidade do grafite e do papel, numa figuratividade em que o sujeito do enunciado na posição em que se encontra e o relógio, ao marcar 2 horas e 5 minutos, interrogam o espectador. Quem sou eu que te olho? A pose é um resgate da posição da modelo, que necessita estar parada, disponível para ser observada. De algum modo, essa estrutura, que poderia ter sido vivenciada nas aulas de Modelo Vivo, é evocada e atualizada no desenho da artista.

\title{
A apropriação dos objetos do cotidiano, o colecionador
}

\begin{abstract}
Tenho uma caixa cheia de objetos. Tinha muitos novelos. Tem uns trabalhos feitos a partir destes novelos. Teve uma fase em que eu ficava desenhando novelos, teve a fase dos ossos. Guardei uma arcada dentária e fiz vários trabalhos desta arcada. Recolho objetos que fazem parte do cotidiano, imagens que eu via numa revista, num jornal [...] guardava as imagens que me interessam. (PEZZIN, 2018)
\end{abstract}

Muitos artistas colecionam objetos e os incluem em suas obras. Podemos exemplificar com o artista Rubens Gerchman, que arquivava fotografias e recortes de jornais para inseri-los em seu processo criativo (BERG, 2016).

Os recortes de jornais e a coleção de objetos ordinários, tais como novelos de barbante, pedaços de ossos de um esqueleto desfeito (utilizado nas aulas de desenho anatômico do Centro de Artes), a arcada dentária e um martelo quebrado, entre outros objetos, denotam como se organiza o processo de criação da artista Nelma.

A coleção composta por objetos e recortes forma um repositório de guardados, memórias e de informações, utilizadas em seu processo criativo do seguinte modo:

1- recortes de jornais, revistas, entre outros papéis (como referência para um fato, acontecimento que naquele momento a impressionou e por esse motivo era guardado para um uso futuro); 


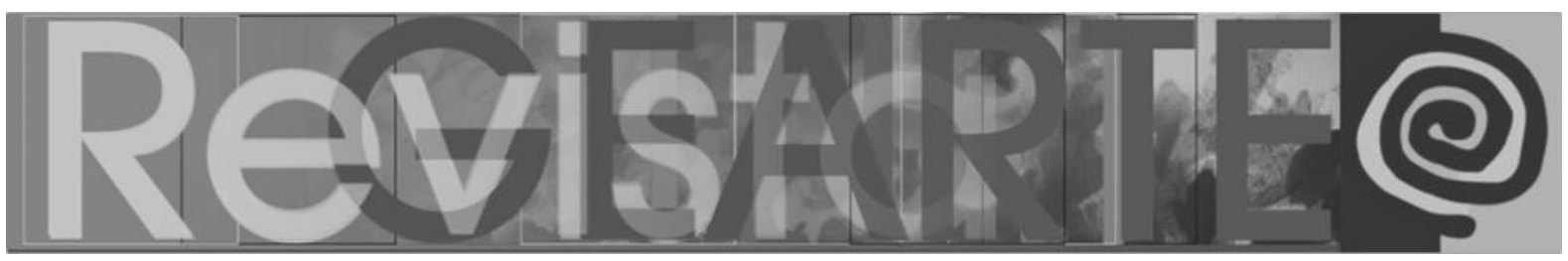

2- cadernos de anotações (cadernos de desenho sem pauta, em formatos variados, são utilizados para memorizar os pensamentos em esboços pequenos e rápidos e podem ser transformados em desenho, pintura ou gravura; neles constam desde anotações de palavras e frases, à descrição de materiais, técnicas e cores a serem incorporadas em trabalhos futuros);

3- objetos recolhidos de casa ou encontrados ao acaso apropriados pela artista para praticar o desenho, adquirindo o estatuto de objetos modelos.

A coleção desses objetos se dá ao acaso (como no caso do martelo e ossos) descobertos após perderem suas funções práticas, mas pode ser intencionada, como a coleção dos novelos ou, ainda, ocorrer por ajuste de sensibilidades (como é o caso dos recortes das imagens dos jornais e/ou revistas).

Inseridos no seu fazer criativo, assumem posições actanciais diversas tanto no processo como na obra "finalizada e exposta". No caso dos objetos (novelos, ossos, martelo), a interação entre eles e a artista se dá numa temporalidade extensa e contínua. Retirados do contexto da cotidianidade e destinação, qual seja, de amarrar, para o novelo de barbante; de estar junto com outras partes e ser um outro, para o esqueleto; ou de uma função prática, como a de martelar, para o martelo. Esses objetos assumem a posição de "modelo" para a artista. O interesse neles está em sua materialidade e forma a serem exploradas e apropriadas [...] por sua compleição, sua consistência (seu peso, sua textura, seu calor) e sua mobilidade específicas, de significar imediatamente para outro corpo (por "contágio") o sentido vivido de seu próprio viver" (LANDOWSKI, 2017, p. 120). O desenho surge da práxis da desenhista e de sua formação. Ele não é só ideia, precisa desse outro corpo para interagir e da repetição para que a plasticidade se aproprie do parecer da forma ou do próprio "ser" das coisas (LANDOWSKI, 2017, p. 110). O desenho é pesquisa e exercício, é construção expressiva plástica e figurativa. 


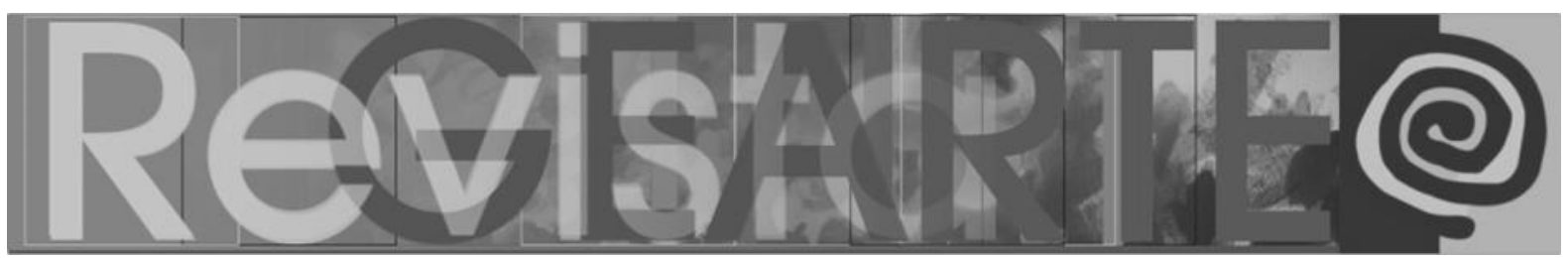

Associada à construção figurativa e plástica, a investigação das materialidades distintas agregadas ao desenho é explorada nesse processo poético da artista, conforme encontramos no catálogo Nelma Pezzin: pinturas e desenhos (2008), da exposição realizada em 2008 na Galeria de Arte Espaço Universitário da UFES (GAEU-UFES).

Essa exposição reuniu pinturas, desenhos e gravuras ou a mescla de duas a três dessas linguagens em uma única obra. Por tratar-se de uma exposição individual, trouxe obras de 1990 a 2008, sendo que a contemplação desse catálogo possibilita ao leitor observar as marcas desse percurso vivido pela artista. Entre as obras dessa exposição, elegemos as que reúnem desenhos realizados em 2000 e 2008, inseridas em dois "livros de artista".

Os livros de artista podem englobar tanto uma produção heterogênea quanto uniforme. Em termos formais - embora mantenham características que os aproximam, tal como desvelar processos de criação - são registros de estudos que podem ser reapropriados ou não pelos artistas ou, ainda, constituírem-se e serem apresentados como produtos, obras.

Os "livros de artista" elaborados por Nelma constituem-se como obras únicas (sem reprodução ou tiragem), podendo assim ser incluídos como livrosobjetos ou, ainda, como a própria artista os nomeia: "livro memória".

O livro constitui-se como um suporte de uma ou várias narrativas. Ao que parece, os da Nelma contêm narrativas experimentais da artista e de seu fazer.

Como um sujeito que sabe e pode desenhar, o que a move aqui é o querer fazer e assumir outras competências. Considera-se nisso o "[...] desejo, ou uma necessidade na origem de uma ação [...]" (TATIT, 2001, p. 30), e esta é a de desenhar. O que já estava conquistado pela regularidade do ato programado e repetido por meio da competência do "fazer" e do "saber-fazer" regulava a performance. Nos "livros da artista", o uso de técnicas já conquistadas e o suporte 


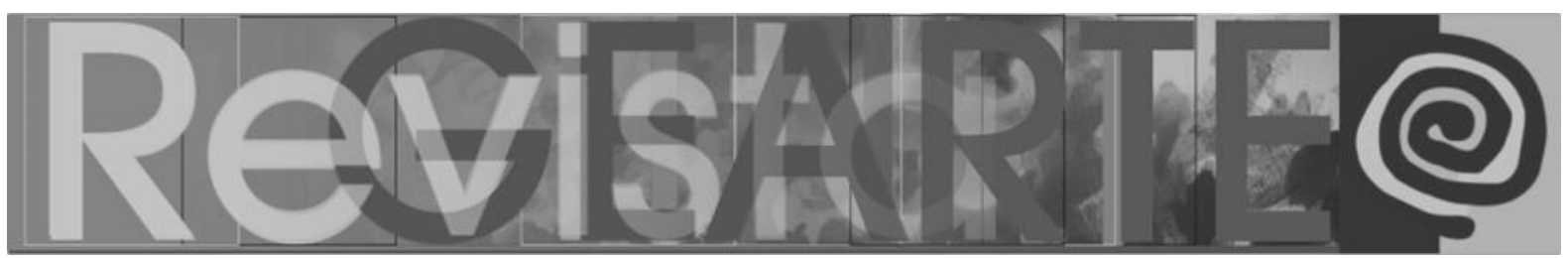

papel para o desenho são rejeitados e substituídos pelo desafio de tentar outras experiências.

Para a compreensão dessa escolha, é importante lembrar a natureza antropocultural que a narrativa possui na semiótica. Em consequência, implica o atendimento a injunções sociais que extrapolam o âmbito do pessoal (TATIT, 2001). Desse modo, o artista, ao assumir um papel de sujeito "inovador", "criativo", "inventivo", não se submete às fórmulas, técnicas, temas e figuratividades já conquistadas. Como diz Nelma,

\begin{abstract}
O trabalho de arte nunca vai se completar. Você está sempre mexendo, em movimento. A impermanência é total e aquela angústia de você fazer e, não ter aquilo completo. Faz parte de todo trabalho de arte. Você vai estar sempre buscando em outro e outro, e outro. Não gosto daquele trabalho que congela. Criar um modelo e seguir aquilo ali, por que ficou legal, por que vendeu, porque as pessoas acharam legal. Sou inquieta, faço e daqui a pouco acho que aquilo não dá. (PEZZIN, 2018)
\end{abstract}

$\mathrm{Na}$ "fala" da Nelma há o percurso narrativo de um sujeito modalizado pelo querer, mas que se recusa a trilhar caminhos já definidos. Tal como preconiza Oliveira (2010, p. 179), esse é o sujeito que processa o sentido, descobrindo-se nos caminhos e esse é um "descobridor em ato".

\title{
Memórias figurativizadas
}

No recorte dessa produção elegemos algumas produções da artista para expor o que já comentamos e complementar com outras observações.

O "livro da artista", como a maioria dos formatos de livros, tem sentido vertical e tamanho de $30 \times 40 \mathrm{~cm}$. Além do sentido e formato, as figuras de 4 a 11 possuem outras similitudes. Estar no "livro da artista" é fazer parte de um processo de investigação. $\mathrm{Na}$ intertextualidade com o título: Série: livro de memórias podemos supor tratar-se de narrativas provenientes de um tempo passado e sequencial, atualizado pelo desenho. Cada uma delas constitui-se como um desenho autônomo, entretanto a reunião delas na série faz com que o encadeamento entre elas testemunhem o movimento expressivo e as escolhas que 


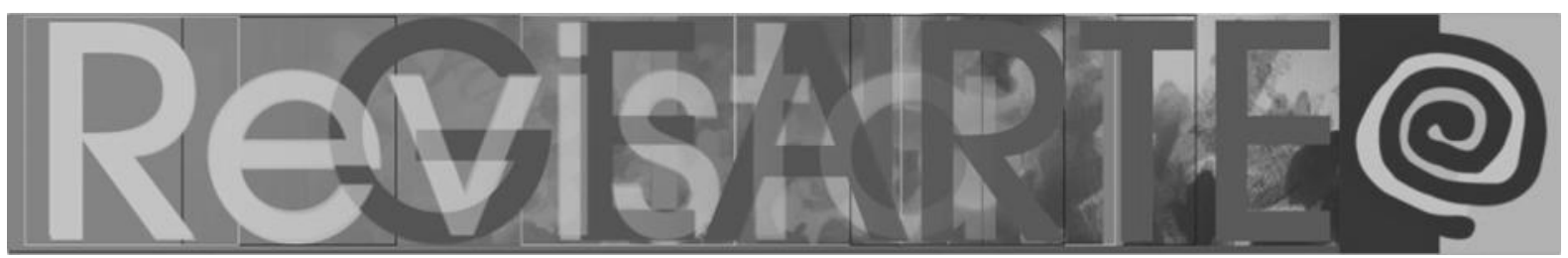

a artista faz. Centralizados e em posição vertical, os novelos, ossos, pregos, martelos, caveira, dentes, por sua vez, carregam, eles mesmos, memórias de funções distintas, que não exercem mais. Na investigação da plasticidade, temos um confronto no ato de desenhar sobre esse processo o comentário de Guimarães (2008, p. 5) sobre os desenhos contidos no livro:

[...] nele as figuras de ossos, martelos e novelos de linha são feitos a nanquim com bico de pena. São a princípio desenhos, porém sobre tecido, um dos suportes tradicionais da pintura. Além disso, cada página recebeu um banho de cera, uma imersão do desenho na matéria pictórica. O resultado é curioso: as linhas ficaram trêmulas e hesitantes $[\ldots]$.

Figuras 4,5,6,7 - Série livro de memórias, 2000, 30X40cm
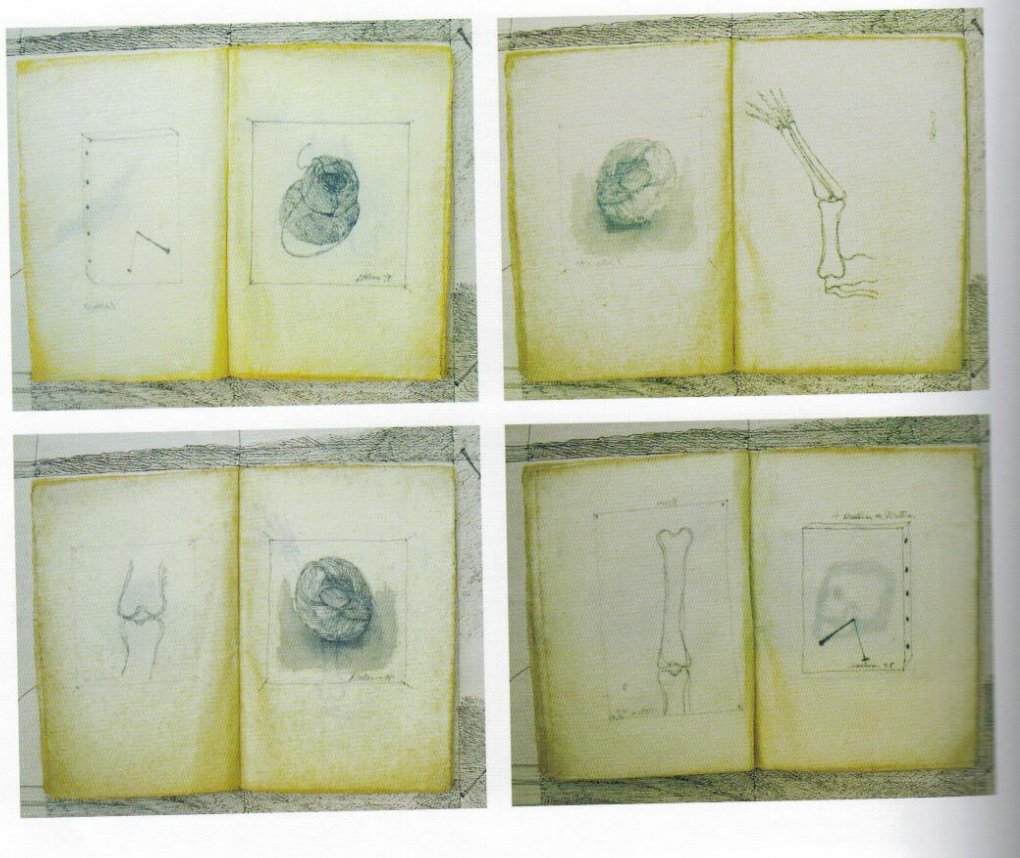

Fonte: Catálogo da Exposição na GAEU 2008. 


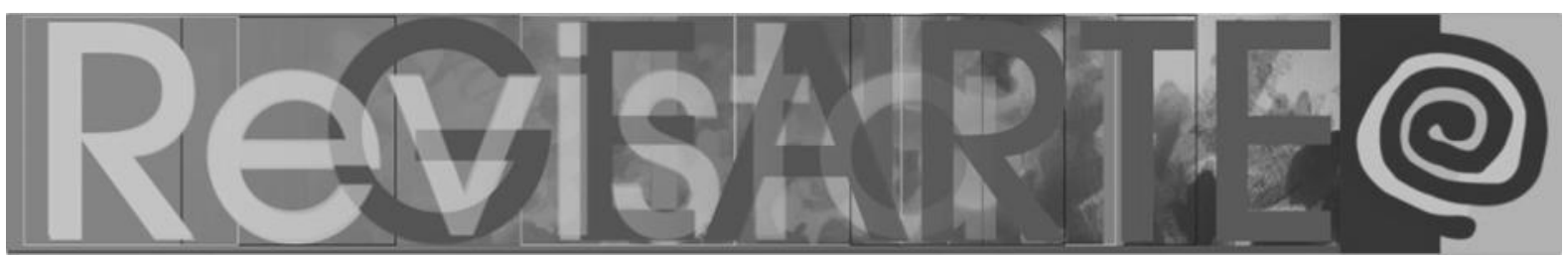

Figuras 8,9,10,11 - Série livro de memórias, 2000, 30×40 cm
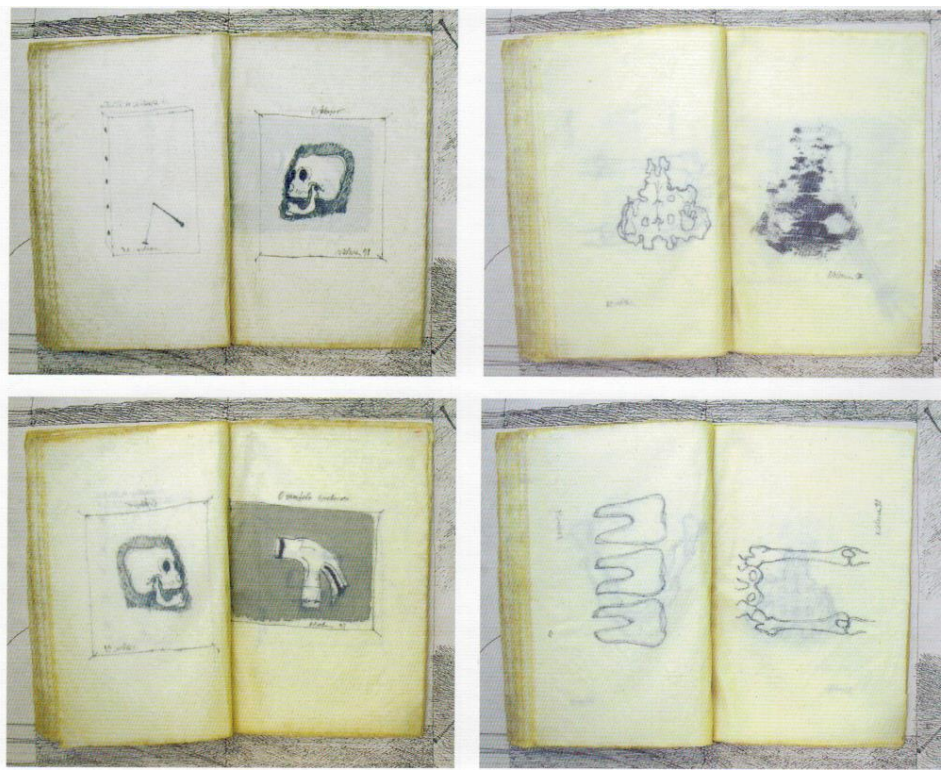

Fonte: Catálogo da Exposição GAEU 2008.

Nessa combinação e apropriação de uma linguagem com outra, desenho com a pintura, como na série livro do ano 2000, a posição actancial da materialidade do tecido que é suporte e a inclusão da camada de cera sobre o desenho edificam uma outra temporalidade, mais lenta e pesada ao ato outrora rápido e leve do desenhar.

O interesse investigativo se dá tanto pela exploração do objeto-modelo como pela proposta de um discurso artístico em que a matéria, ela mesma, confere a espessura do sensível ao produto apresentado. Contudo, ao que parece, mesmo esse produto-obra poderá ainda sofrer outras alterações, como é o caso do desenho da Figura 12 da Série: O paraíso perdido.

A começar pelo título, temos a retomada do léxico "paraíso", como a marcar etapas de um percurso investigativo de produção em que as relações intertextuais entre o verbal e entre o verbal e o plástico podem assumir diferentes papéis: tanto o de reunir em sequências figuratividades próximas e combinadas como a de coração e novelos. Ou o contrário, com o propósito de distinguir uma série da outra, ou do desenho único realizado em 1977, exposto neste texto na Figura 1. 


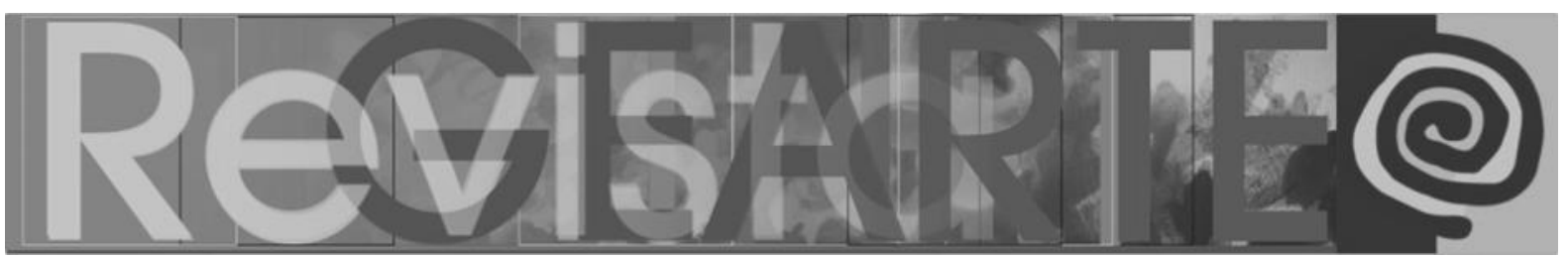

Figura 12 - Série o paraíso perdido, 2008, 30 × $40 \mathrm{~cm}$

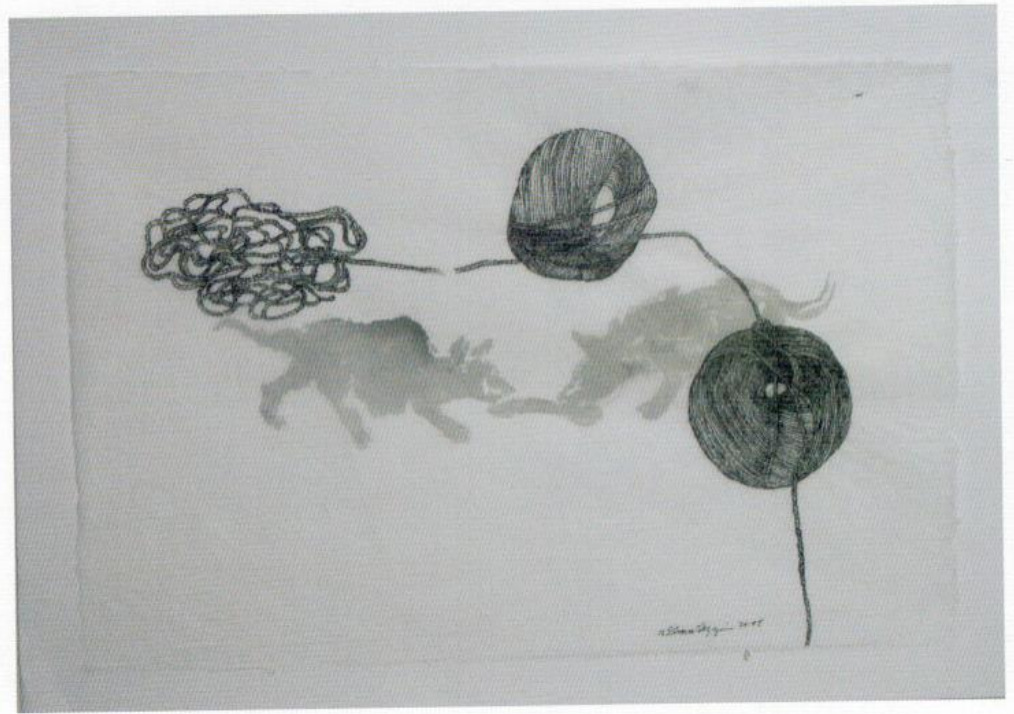

Fonte: Catálogo da Exposição GAEU 2008.

A sobreposição de figuras do desenho remete à técnica da gravura (mancha $x$ linearidade), contudo estão no mesmo suporte de tecido e também recebem a camada de cera. Observando a figuratividade da cena composta de seis figuras, três na camada de baixo e três na de cima, percebemos a existência de uma organização plástica que se mantém na produção da artista. Um rigor compositivo, dado pela centralização da cena, que tem na estética clássica seu fundamento. Com leitura da esquerda para a direita, acompanhando o fio que termina na parte de baixo do retângulo compositivo, o que vemos é a figurativização da luta por um osso, entre dois cachorros. Na camada de cima, o desenho possui uma outra figuratividade e plasticidade, como a apontar caminhos diversos. O que está à direita encontra-se figurativizado como um emaranhado desorganizado de fios, direcionado na horizontalidade para o outro novelo, à sua esquerda. Contudo, há uma ruptura entre eles. Aqui, a relação com a figuratividade que está no desenho de baixo é reiterada. A seguir, os dois novelos seguintes encontram-se perfeitamente organizados e pendem para fora, em busca do que é externo ao suporte que os contêm.

Ao que parece, e como aponta Guimarães (2008, p. 5): "Há também nas obras da artista uma forte relação entre matéria e figuração" [...], neste proceder o 


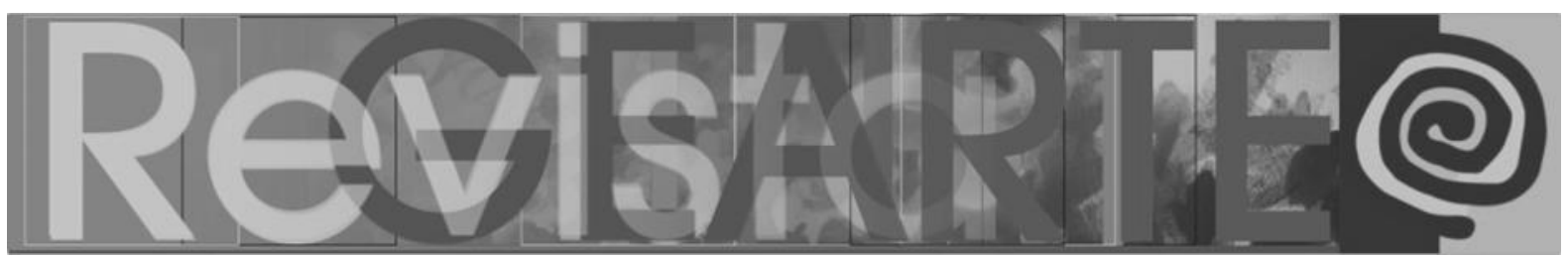

que está em jogo constitui-se como "[...] uma experiência do sensível frente à presença inapelável das coisas palpáveis".

Nessa perspectiva, desenho não é somente técnica, é um ato de interação que envolve ajustes de sensibilidades entre sujeitos; não há mais a separação entre sujeito e objeto. O desenhante, a materialidade e o desenho são constituídos por um só ato, um só corpo. Nos comentários sobre o seu processo de criação Nelma revela:

\begin{abstract}
O desenho é uma coisa mais imediata o material vai te dar possibilidades diferentes. Estava usando muito nanquim. Faço direto. Mas é variado. Nesta produção fazia pequenos pedaços em papel transparente e a ideia é realmente não ter uma coerência. Ser dissonante.

No caso da pintura, por mais que eu tentasse programar. Usava e fazia aquela mancha. E com lápis de cor. Na pintura os imprevistos são bem maiores. Cada linguagem aquele caderno anotava coisas o que eu queria que fixasse. Os ícones, pegava coisas. (PEZZIN, 2018)
\end{abstract}

O ser junto, educação partilhada.

\begin{abstract}
Venho de uma geração que tinha esta liberdade de produzir e de experimentar, e ao mesmo tempo ter seriedade de ter de mostrar o produto...e incentivado a entender o que estava produzindo. Acho que as universidades mudaram bastante o ensino, acho que se tem mais conceitos do que o refletir sobre a produção, mas como fazer reflexão sem produto? (PEZZIN, 2018)
\end{abstract}

$\mathrm{Na}$ narrativa da artista ficam expostos os valores da liberdade e da experimentação em um ensino superior da Arte que mantém a especificidade das disciplinas artísticas, seus processos e técnicas. Foi nessa estrutura de existência dos ateliers de arte e de disciplinas que a artista se formou. Os ateliers que compunham a base da formação do artista do curso de Bacharelado na década de 70, e que perdurou por muito tempo no Centro de Artes da UFES, destinavam salas específicas para cada uma das linguagens: pintura, escultura e para cada uma das gravuras (metal, xilogravura e litogravura). Em outro prédio, as demais disciplinas reunidas em torno do Departamento de Artes Industriais tinham salas especificas para comportar o laboratório de fotografia, as aulas de cerâmica e outras que cultivavam em suas propostas a pedagogia da Bauhaus, principalmente no que 


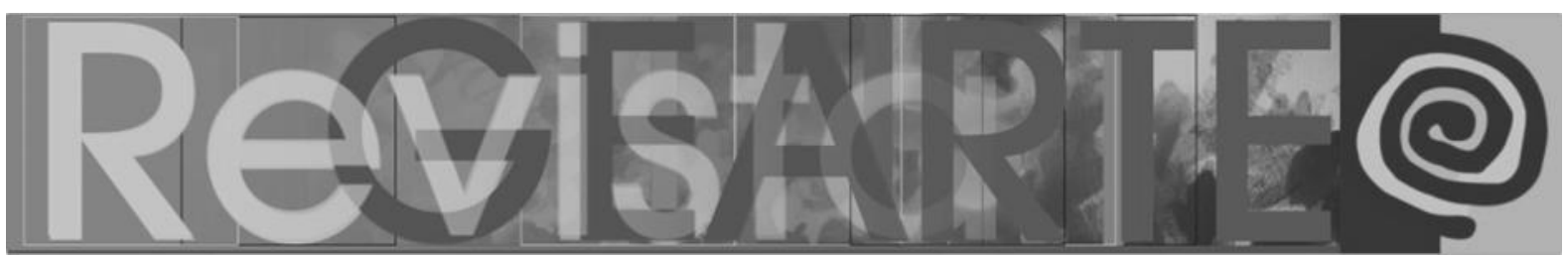

tange à exploração de oficinas de arte aplicada (joalheria, marcenaria, tecelagem, estamparia entre outras). Nessa perspectiva, fazer arte é fazer um produto. Esse fazer necessita de um espaço apropriado com instrumental que comporte as especificidades das produções e de um professor que desempenhe o papel de mestre ou de mediador. Aludindo à estrutura das escolas de Belas-Artes do século XIX, Duve (2012, p. 169) destaca três aspectos: a articulação da especificidade e autonomia da disciplina artística; a existência do mestre e o reconhecimento desse como um profissional de uma disciplina (sujeito competente para transmitir o saberfazer), e a existência de uma infraestrutura técnica. Entretanto, nem na ocasião da formação da Nelma existia no Centro de Artes da UFES essa tríade pautada nos moldes das escolas de Belas-Artes. Desde aquela época, embora os professores se especializassem em uma das linguagens (pintura, gravura, escultura, entre outras) transitavam por mais de uma ou por várias outras linguagens. Nesse movimento, distanciavam-se daquele profissional da Escola de Belas-Artes e aproximavam-se de uma outra concepção de mestre ou de professor que é mediador. Nele, a atuação desse sujeito tem como valor não mais a transmissão da técnica, mas da concepção estética que os prepare a atuar como artistas. Nessa concepção remanescia o "ser junto" (LANDOWSKI, 2016, p. 14), conforme podese inferir na declaração da artista e professora:

\begin{abstract}
A perspectiva de também produzir e ao mesmo tempo de passar para alguém que no caso é um aluno, você não encara como aluno. Pois a arte é um processo num vai e vem, não dá para ensinar tudo, pois você também está aprendendo junto, este é o papel do professor de arte, ele tem de estar o tempo todo. Olhando para o seu trabalho, a sua pesquisa, e junto como o aluno você vai... acho que é uma forma de sobreviver dando aula e ao mesmo tempo produzindo. (PEZZIN, 2018)
\end{abstract}

Nessa forma de educar, a quebra da hierarquia e da verticalidade do "saber do mestre" é substituída pelo "aprender junto" e assume os modos processuais da própria arte. Conforme Landowski (2016, p. 14), a filosofia implícita desse conhecimento tem em conta um "saber em ato", próprio do interacionismo. Ao comentar sobre o seu papel de docente articulado ao de artista, percebemos que um outro programa narrativo é anexado, o de pesquisadora, sendo esse terceiro o 


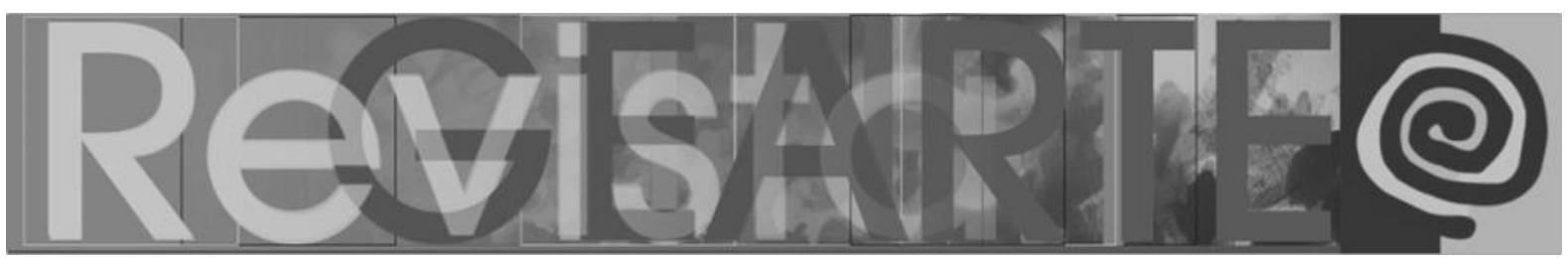

que impulsiona os demais. Se o sujeito está modalizado pelo dever, querer, poder e saber é a continuidade e sua inserção na investigação que o faz-ser. É o que observamos no depoimento a seguir:

Tinham as semanas de arte, depois e os festivais que foram muito importantes. Neste eu já estava como professora, mas eu não deixava de frequentar por ser professora. Sempre quis continuar a pesquisa e sempre quis coisas novas, então ia para os festivais, embora fossem mais voltados para os alunos, inclusive de fora. Eram quinze dias de muita produção. Fiz serigrafia com Dionísio Del Santo, em 1977 e depois mais tarde. (PEZZIN, 2018)

Não basta ser sujeito competente que sabe-fazer, nem permanecer na transmissão no papel do mestre em que são enunciados princípios a serem aplicados aos estudantes. Um professor artista, tal como Nelma, enuncia os comentários sobre o processo e o produto. Recupera o papel que viveu como "bolsista arte" e o devolve aos estudantes de "agora", assumindo uma educação que é partilhada. Para Oliveira (2010, p. 180):

A exploração da arte é fundamental, pois no seu universo criativo, ela presentifica em buscas e várias procuras os modos e meios de existir. Cabe ao educador mostrar os caminhos da busca de sentido do artista e fazer desses uma reflexão para a vida. Cabe ainda desenvolver a aquisição dos códigos para que cada sujeito tenha habilidades de processá-los e dispor de mais formas de expressão.

Finalizamos com a narrativa da professora artista, que assume esse duplo papel como uma forma de vida ou uma prática de vida, pautada pelo estar junto com os estudantes no permanente processo investigativo de produção. É a artista que persistiu em seu "apego" à materialidade das pedras litográficas e à gestualidade que esse suporte permitiu inscrever e reproduzir.

Mais recentemente teve o Grupo Célula de gravura formado por alunos,
eram meus ex-alunos que resolveram fazer litografia. Era uma área
questionada, para que tinha na UFES, aquelas pedras? E eu tinha um
apego àquelas pedras. Passadas várias gerações, os alunos faziam a
disciplina e pronto. Mas estes não, esta geração resolveu encarar e
achavam a coisa mais incrível o processo artesanal, aquelas máquinas
do início do século XX, as bacias de ágata que eu usava, mexer com
ácido! Nunca imaginava que iria encontrar alunos com tanto interesse!
A pedra não é para reproduzir imagens, ela é para ser entendida, o que
você pode retirar dela. Ela tem uma vida própria. Ela vai sendo polida e
as camadas vão saindo. Fica uma memória de séculos. Pertenciam a 


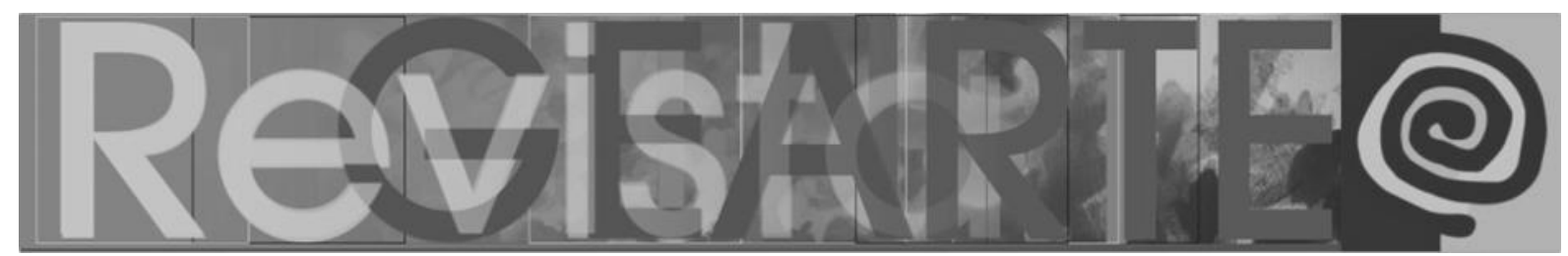

antigas gráficas que reproduziam rótulos e logotipos de produtos. E vai retirando as camadas e vai refazendo o desenho. Cria uma coisa bonita. Fica o mistério. Como chegar a desenhar, os materiais e como essa imagem vai sair no papel, fascinava as pessoas que viam. Este grupo começou a trabalhar de forma independente, fizemos exposições juntos, e eles continuaram frequentando o atelier. É um grupo que está aí, ainda ativo um deles ficou como professor voluntário. Este grupo estando juntos foi muito bom, pois produção da lito é muito pesada. Foi importante esta troca. O ensino é troca. Sempre encarei o aluno como uma pessoa que está pesquisando juntos. (PEZZIN, 2018)

O ensino é troca e não transmissão, e a educação é partilhada. A "forma de vida" da professora artista, ou o que a faz-ser, tem na articulação das práticas artísticas e docentes a sua própria constituição como sujeito. É por meio das qualidades do sensível presentes na materialidade e na poética de seu fazer artístico que elas são operadas, permutando as posições de educador e do educandum, e a "matéria" a ensinar perde seu caráter tradicional de saber objetivado para vir a se confundir com o próprio processo interacional (LANDOWSKI, 2016, p. 11).

\section{Referências}

BERG, Thayane Vicente Vam de. Arquivos de artistas plásticos: processo de criação artística nos documentos de Rubens Gerchman. 2016. Dissertação (Mestrado Profissional em Gestão de Documentos e Arquivos). Universidade Federal do Estado do Rio de Janeiro. Programa de PósGraduação em Gestão de Documentos e Arquivos, Rio de Janeiro, 2016.

BISMARCK, Mário. Desenhar é o desenho. In: SEMINÁRIO OS DESENHOS DO DESENHO: NAS NOVAS PERSPECTIVAS SOBRE ENSINO ARTíSTICO, 1., 2001, Porto. Anais [Actas]... Porto: Faculdade de Psicologia e de Ciências da Educação, Universidade do Porto, 2001. p. 55-58.

BUORO, Anamelia Bueno. Olhos que pintam: a leitura da imagem e o ensino da arte. São Paulo: EDUC/FAPESP/Cortez, 2002.

DUVE, Thierry de. Fazendo escola (ou refazendo-a?). Trad. Alexânia Ripoll. Chapecó: Argos, 2012.

FIORIN, Jose Luiz. Práxis enunciativa. In: PERNAMBUCO, Juscelino; FIGUEIREDO, Maria Flávia; SALVIATO-SILVA, Ana Cristina. (Orgs.). Coleção Mestrado em Linguística. Franca: Unifran-5, 2010. p. $53-73$.

GREIMAS, Algirdas Julien. Sobre o sentido: ensaios semióticos. Trad: Ana Cristina Cruz Cesar et all. Petrópolis, Vozes, 1975.

GREIMAS, Algirdas; COURTÉS, Joseph. Dicionário de Semiótica. Trad. Alceu Dias Lima et al. São Paulo, Cultrix, s/d.

GUIMARÃES, Lincoln. Projeto de deriva. In: PEZZIN, Nelma. Nelma Pezzin: pinturas e desenhos. Vitória: EDUFES, 2008. p. 5-6.

LANDOWSKI, Eric. A sociedade refletida. Trad. Eduardo Brandão. São Paulo: EDUC/Pontes, 1992. 


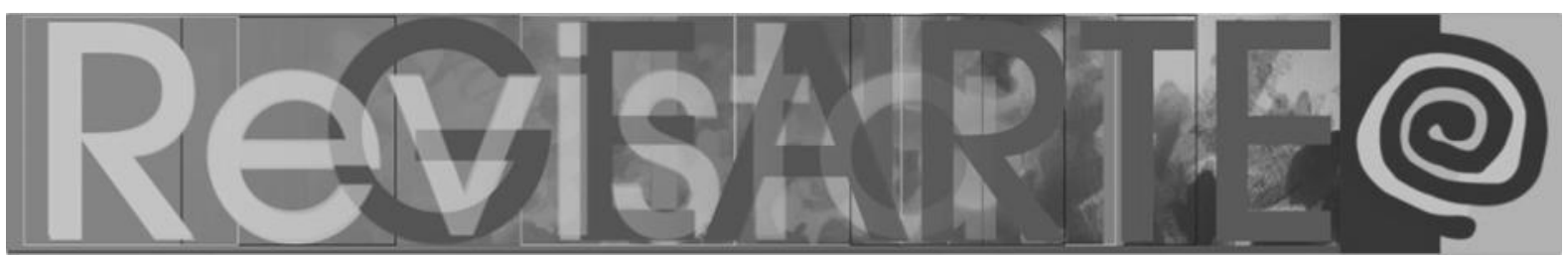

LANDOWSKI, Eric. Viagens às nascentes do sentido. In: SILVA, Ignácio. (Org.). Corpo e Sentido: a escuta do sensível. São Paulo: Editora da Universidade Estadual Paulista, 1996. p. 21-44.

LANDOWSKI, Eric. Gosto se discute In: LANDOWSKI, Eric; FIORIN, José Luiz. (Orgs.). O gosto da gente, o gosto das coisas, São Paulo: Educ, 1997. p. 97-160.

LANDOWSKI, Eric. O olhar comprometido. Galáxia: Revista Transdisciplinar de Comunicação, Semiótica, Cultura. Programa de Pós-Graduação em Comunicação e Semiótica da PUC-SP, n. 2, p. 19-56, 2001.

LANDOWSKI, Eric. Interações arriscadas. Trad. Luiza Helena Oliveira da Silva. São Paulo: Estação das Letras e Cores: Centro de Pesquisas Sociossemióticas, 2014.

LANDOWSKI, Eric. Regimes de sentido e formas de educação. Entreletras, Araguaína/TO, v. 7, n. 2, jul/dez. 2016.

LANDOWSKI, Eric. Com Greimas: interações semióticas. São Paulo: Estação das Letras e Cores: Centro de Pesquisas Sociossemióticas, 2017.

OLIVEIRA, Ana Claudia. Sabor de Sabor Pão de Açúcar, à luz da semiótica. In: Compós XIIEncontro Anual da Associação de Programas de Pós-Graduação em Comunicação-2003, Recife. Caderno de textos: Produção de sentido nas mídias, 2003, v. 1, p. 56-74. Disponível em $<$ http://www.unicap.br/gtpsmid/artigos/ana-c.pdf >. Acesso em: 22 ago. 2018.

OLIVEIRA, Ana Claudia. Entrevista com Ana Claudia de Oliveira por Sandra Regina Ramalho e Oliveira. Palíndromo, Periódico do Programa de Pós-Graduação em Artes Visuais CEART/UDESC, Florianópolis, v. 5, n. 10, p. 178-197, 2013.

PEZZIN, Nelma. Catálogo da exposição: Nelma Pezzin: pinturas e desenhos. Vitória. EDUFES, 2008.

PEZZIN, Nelma. Entrevista concedida ao Grupo de Pesquisa GEPEL em 10/05/2018.

TATIT, Luiz. Análise semiótica através das letras. São Paulo: Ateliê Editorial, 2001.

ZAMBONI, Silvio. A pesquisa em Artes: um paralelo entre Arte e Ciência. Campinas: Autores Associados, 1998.

\section{Moema Martins Rebouças}

Graduada em Licenciatura em Desenho e Plástica (1981), Mestrado em Educação (1995) ambos pela Universidade Federal do Espírito Santo. Doutorado em Comunicação e Semiótica pela PUC de São Paulo (2000). Pós-doutorado pela Universidade de Belas Artes do Porto. Atua como professora do Programa de Pós-Graduação em Educação da UFES. Participa do grupo de pesquisa do Centro de Pesquisas Sociossemióticas - CPS das instituições PUC/SP, USP e CNRS de Paris e é líder do grupo de pesquisa GEPEL /Cnpq. Bolsista de produtividade do Cnpq (2016 a 2019).

ORCID: https://orcid.org/0000-0003-4276-4853

E-mail:moemareboucas@gmail.com

Currículo: http://lattes.cnpq.br/4414451806305375

Recebido em 26 setembro de 2019

Aceito em 10 de dezembro de 2019 